\title{
The Queer Dialectic of Whitman's Nation: "Let" in "Respondez"
}

Let the Asiatic, the African, the European, the American, and the Australian, go armed against the murderous stealthiness of each other! Let them sleep armed! Let none believe in good will!

Walt Whitman, "Poem of the Proposition of Nakedness," I 856

$\mathrm{O}$ RIGINALly PUBLISHED AS "POEM OF THE PROPOSItions of Nakedness" in I856, then without a title in I860, the poem that we know as "Respondez" only appeared as such in the 1867 and I 87 I-72 Leaves of Grass. If, as Sam Abrams claims, "Respondez" is "a poem widely regarded as the most important in the entire Whitman corpus" then it occupies a strangely marginal position in that corpus (32). ${ }^{1}$ Easily overlooked because of its exclusion from the first and final editions, the poem is better known to a few critics of Whitman than it is to a general readership. ${ }^{2}$ It is probably best known to other poetsand is, ironically, more often printed in anthologies and selections than "complete" editions of Leaves of Grass. ${ }^{3}$

"Respondez" clearly stands out, although theories of why are not forthcoming. Louis Zukofsky famously wrote that it was "Whitman's greatest poem," quoting the work in its entirety but without further comment at the end of Prepositions+ (2 I8-2 I ).4 Likewise in 1947 William Carlos Williams claimed it as exemplary of "a new formal necessity touching all verse" (qtd. in Abrams 32), going on to read twenty-five lines of the poem also without further comment. In not commenting, Zukofsky and Williams alert us to its slipperiness, for quoting "Respondez" is far easier than offering an interpretation or capturing it within a general framework. 
Nonetheless the poem as a whole merits careful attention, if only because here we have a different Whitman from the familiar one: a Whitman who is not the national poet of America, but rather a prophet of a queer and anarchic global modernity. By looking closely at the form, specifically Whitman's use of the stylistically anaphoric "Let," this essay reveals instability at the heart of the problem of interpreting "Respondez." As Marshall McLuhan seemed to recognize in his resetting of Whitman's lines (Fig.I), the role of this small word is much larger than one might think. Grammatically, "let" can function as a first or third person imperative auxillary, but it can also function as an optative subjunctive, expressing desire rather than command. 5 This grammatical instability casts light on the complex nature of the national, or rather international political engagement of "Respondez," and on the changing relation of Whitman's poetry to global capitalism from i 856 to 1892 .

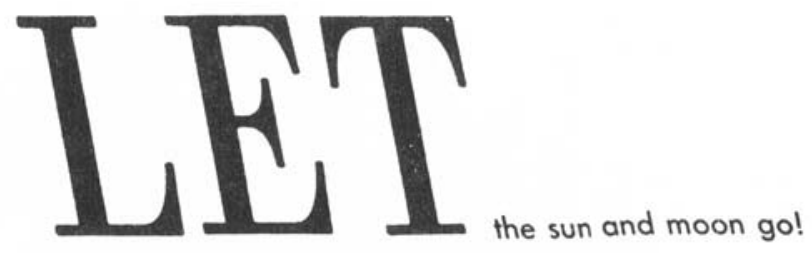

let scenery take the applause of the audience!

let there be apathy under the stars!

Fig. I. Marshall McLuhan's Resetting of Whitman's "Respondez" in Verbi-Voco-Visual Explorations.

Let us go back to the beginning however, and start with the original title: "Poem of the Propositions of Nakedness." Ostensibly this title refers to a line that appears three pages later: "Let us all, without missing one, be exposed in public, naked, monthly, at the peril of our lives! Let our bodies be freely handled and examined by whoever chooses!" (319). Since there is so little nudity elsewhere in the poem, however, we assume that the title and this line are not literal "Propositions of Nakedness," but are supposed to be read metaphorically. That is, Whitman's urging of nudity is emblematic of a more general tendency in many of the other lines-a tendency which might aptly be described as the stripping of social norms. 
Before we follow this interpretation further, it is worth asking, to what extent is this spoken as a poem, and to what extent as a proposition? Why did Whitman awkwardly duplicate the of-phrase in his title: "Poems of the Propositions of . .."? And why is nakedness privileged? The first part of this essay demonstrates how our reading of these lines can change according to how we interpret both the term "proposition" and the "Let." Whitman engages a number of possible definitions of each, and a brief survey of these provides a helpful entry into the complexity of the poem.

In philosophical or mathematical propositions, the word "Let" signals a hypothetical state in which assumptions are stipulated, as in "let $\mathrm{p}=\mathrm{q}$ "; "Let us all = exposed." If Whitman's emphasis on "Propositions" is alluding to this academic form, then he might be read straightforwardly as presenting a conjectural space separated from our own: an imaginary world where public nudity is compulsory. One is reminded of the habits of the original Utopians, the island-nation of Thomas More, where prospective marriage partners must first be exposed naked to each other ("freely handled and examined") regardless of their age or standing. ${ }^{7}$ However, if Whitman's propositions were logical in this strict sense, we would expect the next line to be some form of inference-be it explicit or implicit. Where More uses the Utopians' conjectural marriage arrangements to reflect on the absurdity of English social norms-going on to underline the illogic of carefully inspecting horses before purchase but not taking such cares with spouses-Whitman's propositions contain no similar suggestion of potential social utility. Rather, he seems to be parodying its very possibility.

Beyond being provocative, Whitman's imaginary world appears purposeless, anarchic. Let us then consider an alternate kind of "proposition," turning from reason to sensuality. Why propose something irrational unless it is desired in a fundamental way? The recourse to an unspoken drive serves us better here: the pleasing aspect of the image of everyone publicly exposed. "Let our bodies be freely handled" is effective, partially at least, through the frisson of its erotic charge although it is not explicitly sexual. Registering the libidinal quality, much early criticism focused on this aspect of "Respondez"- even suggesting that this was why it was cut from the final edition. ${ }^{8}$ In this fantasy of a sexual proposition, "Let" takes on a second valence not of a mathematical construction, but of an optative formulation-a way of expressing a 
transgressive or queer desire, and also a way of fulfilling it. The "let" thus functions like a dream in Freud's early theories, where such "optative" formulations indicate not merely wishful thinking but illusory wish fulfillment, as-quoting Kenneth Burke's example from The Philosophy of Literary Form - "when the dreamer, desiring to be rid of a certain person, dreams that this person is departing" $(3-4)$. In this case the poem stands to be interpreted as an oneiric space of personal desires and symbolic fulfillments of those desires.

However, Whitman's proposition of nakedness is primarily compelling neither because it is logical, nor because it is desirable in an erotic way, but rather, one senses, because on a metaphorical level it is liberatory. Even in the remarkably free context of Leaves of Grass, "Poem of the Propositions of Nakedness" has a carnivalesque feel. The human body is thrust into public view, and pretensions to any status beyond that body are exposed. This has a leveling effect. Nudity obliterates an important sign distinguishing humans from animals: "Let the cow, the horse, the camel, the garden-bee-Let the mudfish, the lobster, the mussel, eel, the sting-ray and the grunting pigfish — Let these, and the like of these, be put on a perfect equality with man and woman!" (3 I 8). The Rabelaisian timbre here is telling. After all, when Bakhtin arrived at the terms "carnivalesque" and "grotesque realism" in his reading of Rabelais, it was via an analysis of the Renaissance social system, an analysis directed at discovering the balance between language that was permitted and language that was not. Whitman is engaged with these concerns in his own time. Many of the propositions deal not only with a physical activity itself, but also with the discourse about that activity: with the way we speak about it. Thus the "Poem of the Propositions of Nakedness" begins with "Respondez! Respondez! / Let every one answer! ... let that which was behind advance to the front and speak" (3i6). And the proposition relating to nakedness itself stands to be read under the rubric of a forbidden discourse espoused two lines earlier: "Let men among themselves talk obscenely of women! and let women among themselves talk obscenely of men! (319)." Whitman is thinking of the relation between the sexes here specifically in "talk." Perhaps, therefore, when he says "Let us all, without missing one, be exposed in public, naked, monthly," this "monthly" is not meant as merely arbitrary but also as a reference to what was (and largely remains) unspoken between men and women-menstruation. The line is a call to end the 
silencing of bodily issues, which cannot be explicitly spoken here. The poem strives for precisely the openness it proposes. Whitman's "Let" thus not only adjures society to become more open, but also expresses his own urge to speak the prohibited. It is both optative, and a more literal demand for permission - the right to free speech and action for others and himself. Alongside a logical or illogical utopian space, or a Freudian dreamspace, the poem demands that it be read as a set of propositions freeing discourse.

Permission or release is perhaps the most common and dramatic sense of "Let." It has a mantra-like Biblical counterpart in the words of Moses, commanding Pharaoh, "let my people go"-a resonance which can be heard throughout "Poem of the Propositions of Nakedness." In his 1855 preface Whitman made it amply clear that he thought of himself as a bard or spokesman for his nation: a nation that, according to the well-known Puritan typology, saw itself in the terms of Exodus. To the extent that the poem is America, these lines and the utopianism, sexual desires, and desire for a liberated discourse that they espouse might easily be subsumed under the category of propositions for the future United States.

But Whitman is not just building castles-or nudist colonies-in the air here. If this poem is a blueprint in the sense outlined, it also provides a way of achieving the vision of the future it proposes. As elsewhere, Whitman's language has a performative, Adamic or Cratylic dimension. To an extent, Whitman's plea for a liberated discourse is that discourse presented to us. It is an arrangement that reproduces the aims of Whitman's famous "language experiment"-his attempt to create a language based on natural forms adequate to the task of building an American nation: a language that could serve "the g true real genius character genius of the language underneath our speech, tongue, which is not what the school-men suppose, but wild, intractable, suggestive-perhaps, in time, made a free world's language" (Daybooks 8ro). By taking control of language, Whitman takes control of the nation. As Carla Billitteri writes,

The utopian design of Whitman's poetic catalogues rests on a carefully worked out theory of language, a Cratylic theory that took shape by assimilating the empirical evidence that words, like governments, are not always natural, but must sometimes 
develop on grounds other than nature so as to meet the needs of the people. (62)

In this economy, "Respondez," like "Crossing Brooklyn Ferry," sees Whitman presenting a future self by performing or "incarnating" his words. 9 Since by his own logic, "The United States themselves are essentially the greatest poem" (Leaves [1855] I), in writing his Leaves Whitman brings his projected nation into being in the present, and we, as readers are its first citizens. The imperative "Let" is crucial to this act of creation: it is a species of fiat lux - a way of bringing into being through language. It recalls not only Moses but also the God of the King James Bible, making a new world piece by piece, beginning with the words "Let there be light" and repeating "let" fourteen times in the first few verses. This culminates in the twenty-seventh verse with the creation of man:

And God said, Let us make man in our image, after our likeness: and let them have dominion over the fish of the sea, and over the fowl of the air, and over the cattle, and over all the earth, and over every creeping thing that creepeth upon the earth. (Gen. I.26)

God, of course, created man and woman naked. "Poem of the Propositions of Nakedness" would seem to call for a return of sorts to an Edenic America, perhaps staging in its transgressions a repetition or reversal of the Original Sin. Whitman's utopianism is flavored with a belief in the Promised Land, the implications of which in nineteenth-century literature have been amply noted in works such as R. W. B. Lewis' The American Adam and Perry Miller's Nature's Nation.

㱒

What I have written so far has championed a highly romantic vision of Whitman's "Poem of the Propositions of Nakedness." The poem is utopian, presenting a space of free discourse between the sexes. It idealizes a democratic progress to an Edenic United States through a set of liberal propositions. Reading Whitman through the mythical construction of America, however, dehistoricizes his project. While he may have begun by alluding to Genesis and Exodus, it is well to remem- 
ber that the poem was only named "Poem of the Propositions of Nakedness" in I 856 . His change of title to "Respondez" after the Civil War in I 867 forces one to think more closely about its involvement with war and contemporary history.

Moreover, attempting to look at the whole of "Respondez" consistently as the grand narrative of the Edenic language experiment is far harder than the reading above admits. Most critics see it as an anomaly, "assimilating it to the canon," in the words of Meredith McGill, "as a rare inversion of Whitmanian optimism" (50), and not as an expression of the hopeful voice predominant in the 1856 Leaves. To read this poem as naively utopian is only possible if one is highly selective about which lines one analyzes. While this process may reveal much about the poem, the selection fails to do justice to the depth of Whitman's equivocation. More often than not, "Respondez" is less like a paradise, and more like its opposite: a dystopia, nightmare, or hell.

Nonetheless, although "Respondez" may be a "rare inversion of Whitmanian optimism," the equivocation in which this "inversion" is couched is characteristically Whitmanian. Who can forget the oftquoted retort in "Song of Myself": "Do I contradict myself? Very well then I contradict myself, / (I am large, I contain multitudes.)" (99)? One can see this principle of duplicity operating both within the poem and in his interventions outside it. As David S. Reynolds points out about "Respondez,"

It is notable that at about the same time he wrote this quite disgusting poem he was, in essays for a Brooklyn newspaper, denouncing "the cant of reformers" as "barefaced and disgusting" and was also posing as a pious reformer himself in his article decrying prostitution, explaining that it is unpleasant but necessary "to grope among the muck and slime." ( I I I)

If the first line and later title of "Respondez" elicit a permissive discursive space, inviting us into a democratic forum, then how does one negotiate not only the negative majority of this poem but its sheer contrariness? How could one go about redeeming this poem as "unpleasant but necessary"?

Let freedom prove no man's inalienable right! Every one who can tyrannize, let him tyrannize to his satisfaction! 
Let none but infidels be countenanced!

Let the eminence of meanness, treachery, sarcasm, hate, greed, indecency, impotence, lust, be taken for granted above all! Let poems, judges, governments, households, religions, philosophies, take such for granted above all! (3 18)

Reading these lines, I am reminded not of the optative subjunctive wish, but of the imperative, the "Let" used by rulers to command decrees. Whitman is playing the role of a capricious tyrant in his own poem. He is tyrannizing, throwing democracy to the winds. The extremity of Whitman's propositions here stands to be read not merely as ironic, but rather as a fully sarcastic inversion (or perversion) of the vision of America he presents elsewhere in Leaves of Grass. In these lines, the political intention of the poem appears to work by a form of contrast-through saying the opposite Whitman wards off a dystopic potential: "Let freedom prove no man's inalienable right!" One can easily imagine this spoken in a horrified tone of righteous indignation. One could even interpret his propositions as being like those of Borges' Jaromir Hladík in "The Secret Miracle," who, knowing he must go before the firing squad before he can finish his play, attempts—on the assumption that "reality does not tend to coincide with forecasts about it" - to "invent so that they might not happen, the most atrocious particulars" of his death (I44-45). By the same "perverse logic" or "feeble magic" (I45), Whitman's propositions may be attempting to thwart their realization. Whitman is not merely creating a utopia in the sense of a "eu-topos" or good place, but coincidentally is making a utopia in the alternate etymological sense of an "ou-topos" or no place.

If we impute a horrified tone to Whitman's poem, it is difficult to resist reading many of his propositions as covert rhetorical questions of the type "Let this happen?" —no way!:

Let all the men of These States stand aside for a few smouchers! Let the few seize on what they choose! Let the rest gawk, giggle starve, obey!

Let the infidels of These States laugh all faith away! If one man be found who has faith, let the rest set upon him! Let them affright faith! Let them destroy the power of breeding faith! (320) 
If we replace Whitman's exclamation points with question marks the meaning is reversed; the rhetorical force of the resulting poem exactly contradicts the former. Alongside Whitman's gestures at an apotropaic litany, we hear a sophisticated technique of political persuasion. As such, Whitman is not only warding off potential dystopia but is warning the reader of that dystopia by naming it. The poem, then, cannot be taken solely as Whitman calling on us to permit whatever fills in the line beyond "Let," but rather as a call to arms to prevent such eventualities. We are thrown back not to the theme of nakedness, but to the first line of the poem: "Respondez!"

This dramatic rallying-cry is one that could equally be a headline for an article of the Brooklyn Eagle, and it is clear why this may have seemed a better title in the postwar reform years of 1867 and $187 \mathrm{I}-$ 72. Indeed, in the latter version, Whitman punningly underscores his choice of title, pointing out its continuing relevance:

\section{RESPONDEZ!}

RESPONDEZ! Respondez!

(The war is completed - the price is paid - the title is settled beyond recall;). (333)

In Whitman: The Political Poet, Betsy Erkkila notes that Whitman also added the following parenthetical lines to that edition:

(Stifled, O days! O lands! in every public and private corruption!

Smother'd in thievery, impotence, shamelessness, mountainhigh;

Brazen effrontery, scheming, rolling like ocean's waves around and upon you, $\mathrm{O}$ my days! my lands!

For not even those thunderstorms, nor fiercest lightnings of the war, have purified the atmosphere;). (Leaves [I $87 \mathrm{I}-72]$ 333-34)

Erkkila comments that the lines "specifically responded to the widespread corruption of the Gilded Age," and that, "Whitman suggests that if anything, the war had given a new birth not to freedom but to fraud" (Whitman 264). Certainly one can think of "Respondez" as Whitman's response to the depredations of his contemporary United 
States. It seems to me, however, that corruption, like contradiction, is more central to Whitman's poem than only as a contemporary reference to a "new birth" of fraud. Corruption, as Whitman himself admits, has been there from the beginning- "the atmosphere" was never pure.

Taking "corruption" as the poem's central dynamic, we can read "Respondez" as a tactical parody or corruption of discourses of power. The title, for example, could be regarded not as a rallying cry or call to a democratic forum, but as a version of what Louis Althusser identified as ideological "hailing." In that case the poem would reveal the interpellation of the subject into a set of beliefs, and the imperative to respond ("Respondez!") would be to reveal one's own constructed subjecthood. Developing that reading further, one could, following Judith Butler, see Whitman not only as exposing the interpellation of the subject, but as also resisting this power. As she explains in regard to the term "queer":

Paradoxically, but also with great promise, the subject who is "queered" into public discourse through homophobic interpellations of various kinds takes up or cites that very term as the discursive basis for an opposition. This kind of citation will emerge as theatrical to the extent that it mimes and renders hyperbolic the discursive convention that it also reverses. (232)

When Whitman writes, "Let freedom prove no man's inalienable right!" his performative line, we might say, is corrupting-or queering-the self-evident truth of "unalienable rights" in the Declaration of Independence. In this sense his is a queer politics. 10 Whitman performs the kind of undermining and exposure of power that Michel Foucault described in The History of Sexuality as "reverse" discourse-a discourse whose "paradigmatic example," as Heather Love explains, is the "invention of homosexuality in its modern form out of the sexological, medical, and criminal discourses of the late nineteenth century" (2).

More simply, we could see the setting of this poem in the expanded field of a religious congregation. ${ }^{11}$ "Respondez" would then act as a corrupted sermon on the model perhaps of fanatical homilies of Jonathan Edwards. Whitman's sermon, however, is a forced confrontation with precisely the opposite of religion: "Let the earth desert God, nor let there ever henceforth be mentioned the name of God! / Let there be no God!" (319). One can see here an example of what Sacvan Ber- 
covitch calls the "anti-jeremiad" (I9I). Unlike the standard jeremiad, which was a definitively American form of political sermon, reminding the New Israel that they were God's chosen people even amid their backsliding, the "anti-jeremiad," common among Whitman's contemporaries, used the same rhetorical terms but for more pessimistic ends. ${ }^{12}$ Whitman taps into a popular national religious imaginary, and turns it against itself. This corruption or détournement of the form of the proposition to its opposite can even be applied to the lines about nakedness: "Let us all, without missing one, be exposed in public, naked, monthly, at the peril of our lives! / Let our bodies be freely handled and examined by whoever chooses!" (3 I9). While Whitman constructs a potential ideal, this ideal falls. Beside Whitman's prevailing "meanness, treachery, sarcasm, hate," the proposition could equally well be thought of as terrifying and invasive. "Nakedness" in this sense would stand opposed to an aesthetic "nudity." It calls to mind George Orwell's I 984 and the totalitarian penetration of the private sphere with state authority through surveillance. Whitman's "monthly, at the peril of our lives!" becomes a horrific mockery of organized society. The rhetorical questions become an interrogation process. Our bodies are like those of animals, not in the Bakhtinian sense, but again in Orwell's; we become chattel, or slaves at auction: "Let the white person tread the black person under his heel! (Say! which is trodden under heel, after all?)" (32I). As one progresses through "Respondez," it is as if a row of dominoes were toppling. By enforcing nakedness, Whitman corrupts the liberatory potential of his proposition, abuses the performance of liberty by insisting on it. As ideals become their opposite through their application in "Respondez," so America as Whitman's great democratic space comes into question.

It is relatively easy to think of "Respondez" simply as an attack on some propositions that threaten to come true or have come true. Whitman, however, never offers us a simple response. Many of the lines if read as interrogatives are not rhetorical questions at all but what John Hollander in Melodious Guile calls a form of "poetic questioning." Neither the rhetorical nor the poetic question is intended literally, but where the first seeks to elicit an inevitable, unspoken answer, in the second, "the impulse to prove something" gives "literal way to another mode of figuration" ( 19 ). Its purposes are manifold, including questioning the question itself. "Respondez" is an interrogation process that is 
directed not so much outwards to a specific course of action that needs to be taken, but inwards toward doubting its own premises.

Although the majority of the propositions in "Respondez" anticipate a vehement rejection, there is nothing to distinguish these ironic propositions from the more earnest ones. Moreover, a negative response in itself is not enough. Whitman is asking for another theory, a different option: "Let every one answer!" (3 I6). By juxtaposing the polyvalent propositions, Whitman hopes to create more than just a diatribe. His propositions are arranged to form a dialectic within his poem-a set of contradictions that the poem's reader would have to work out, taking a different position in regard to each issue. If we do not respond, we lose our grip on sense. Like Theodor Adorno's negative dialectics, Whitman aims to produce something positive by means of negation. Such a mode of dialectics, writes Adorno,

is no longer reconcilable with Hegel. Its motion does not tend to the identity in the difference between each object and its concept; instead, it is suspicious of all identity. Its logic is one of disintegration: of a disintegration of the prepared and objectified form of the concepts which the cognitive subject faces, primarily and directly. (I 45)

Thus we have propositions, which instead of merely assuming the terms they present, turn these terms upside down and reappraise their very bases. The poem negates itself:

Let faces and theories be turned inside out! Let meanings be criminal as well as results! (Say! can results be criminal, and meanings not criminal?)

Let judges and criminals be transposed! Let the prison-keepers be put in prison! Let those that were prisoners take the keys! (Say! why might they not just as well be transposed?)

Let the slaves be masters! Let the masters become slaves! (3 19)

Part of the problem with reading "Respondez" is that we seek to reconcile Whitman's political point with a totalizing vision where reconciliation itself is not properly at stake. In fact, Whitman scrutinizes the conceptual language and authoritarian ontologies on which 
the political arguments are based. In order to do this, his meanings themselves must be outside the usual law-untamable. In the hyperbolic terms in which the poem presents them, they declare themselves "criminal." Like Orwell's Thought Police, they make and break their own law while also advocating anarchy: "Let judges and criminals be transposed." Whitman is presenting a critique of American national polity, its structures, democratic and capitalist bases, and indeed also of binaries (of which sex is perhaps the most prominent). As Adorno says, "to proceed dialectically means to think in contradictions ..." (I45). Very well, agrees Whitman: "Let contradictions prevail! Let one thing contradict another! and let one line of my poem contradict another!" (3I 7 ). In this schema, one must be capable of thinking against oneself, of - to continue the Orwellian analogies-doublethink. Conceptual contradiction is necessary for the creation of a language where terms are not merely taken for granted but worked out afresh in every new context. "Respondez" is like a Möbius strip, moving in circles between the inside and outside. The structure torques, constantly throwing us off balance and forcing us to negotiate our own progress between moral and immoral without resolution.

Developing his theory of negative dialectics in the wake of the Second World War, Adorno was looking for a form of "multinational," or "post-national" dialectics. He intended to create a space for issues organized around new non-nationally determined themes such as genocide, death, and nihilism. Whitman may well have intended a similar transcendence of local terminology in his use of the word "Respondez" after the Civil War. As Erkkila has suggested, this strangely misspelled French word has a historically revolutionary flavor. ${ }^{13}$ Like "Salut Au Monde!" which also appeared for the first time in the 1856 edition as "Poem of Salutation," Whitman seems to be addressing an international audience. And it is well to remember that although his "language experiment" begins as a search for an American language, Whitman's sights were set beyond the borders of the U.S., hoping "in time" to make "a free world's language" (Daybooks 810).

This is a direction within Whitman's verse and use of language confirmed by Jonathan Arac. Contending with the Leo Marxian notion that Whitman was one of the first to write in the "American vernacular" (45) and its implied purism, Arac argues that Whitman's language is more that of the popular New York press than of a specific vernacular. 
In this sense, it is as appropriate to talk about Whitman's poetry (as Benjamin talks of Baudelaire's) as based in the experience of the public spaces of international "capitalist modernity" $(54)$ as it is to relate it to Whitman's nationalism. His "nation-building culture," concludes Arac, "was not folk but mass, that is to say capitalist, and from that, as we now say hopefully of the world stretching — as Whitman would see it—westward from China to Poland, real democracy may follow" (58).

While I agree with Arac that nationalism is a perhaps less useful optic than capitalism when reading Whitman, his internationalist reading fails to account for the prominent role of the Civil War in Leaves of Grass. In general the predominate criticism of Whitman's "Respondez" refers, more or less directly, to a fractured nation and to the war. One of the most thorough of these historicist readings is Erkkila's: "The juxtaposition of seemingly absurd propositions with propositions that describe the actual conditions in America in 1856 ," she writes, "intensifies the impression of fracture and dislocation in the political sphere" (Whitman I 40). Here, Whitman is not so much creating a dialectic in his contradictory poem as recreating a political impasse. The poem's interruption of meanings is mimetic of his crisis and of political events. Thus in I860, as his frustration with pretense in the American Union reaches a peak, he includes the lines:

(If it really be as is pretended, how much longer must we go on with our affectations and sneaking?

Let me bring this to a close- I pronounce openly for a new distribution of roles). (Leaves [1860] I66)

And, the lines added in $187 \mathrm{I}-72$ appear to respond to the widespread corruption of the Gilded Age. When the nation began to move toward economic recovery and with the new political regime under the presidency of Rutherford B. Hayes ( I 877-8I), Erkkila suggests "Respondez" became less relevant; she argues that Whitman "lost the revolutionary fire that marked his early period" and implies that the suppression of "Respondez" was symptomatic of his "removing sites of historical struggle from the poems and reinforcing the image of national growth as natural growth" (Whitman 289).14

This reading of "Respondez" as an all-too historically American poem, while temptingly neat, is problematic. Although "Respondez" 
does adapt to the times, it makes far fewer concessions to major political changes than one might think. Crucially, the 1860 edition is largely unchanged from the pre-war I 856 edition. And the 1867 edition is also blind to many contemporary political developments. For instance, the line, "Let him who is without my poems be assassinated" (Leaves [1867] 28I), remains in the poem even after Lincoln's assassination in April r 865; likewise, "Let the slaves be masters! Let the masters become slaves!" $(282)$ is retained after the passage of the Thirteenth Amendment abolishing slavery, again indicating a theoretical rather than strictly topical perspective. Perhaps we shouldn't be too eager to read Whitman's poem as an index of United States political shifts. If, as Erkkila argues, the poem is a representation of Whitman's relation to the fragmented political space of the American Union, then, in terms of its specific content it is only loosely mimetic of the actual health of this Union.

This is not to say that the two are unrelated but merely that the reflective relation between poem and state that operates elsewhere in Leaves of Grass is twisted in "Respondez." If it takes inspiration from contemporary events and policy, it responds to them in its own queer way, even reversing those historical events by their representation or non-representation. That slavery had been abolished may well have been a reason for Whitman to retain it in his poem as an irresolvable ongoing dialectic. The poem might be seen as adapting its own Möbius strip-like structural relation to its compositional base. Consider for instance the Civil War's apparent absence in the poem until Whitman's explicit mention of it in the $187 \mathrm{I}-72$ edition. Whitman mentions it not to assert the poem's historicity but as an attempt to recuperate "Respondez" from history to a continuing, even timeless, valence. Many of the propositions now include words such as "still" or "again" or "forever." In the following passages, the words in bold are missing from the 1856 , I 860 and I 867 editions:

- Let the theory of America still be management, caste, comparison! (Say! what other theory would you?)

Let them that distrust birth and death still lead the rest! (Say! why shall they not lead you?)

Let the priest still play at immortality! 
Let men among themselves talk and think forever obscenely of women! and let women among themselves talk and think obscenely of men!

Let there be wealthy and immense cities—but still through any of them, not a single poet, savior, knower, lover!

Let the preachers recite creeds! let them still teach only what they have been taught!

Let insanity still have charge of sanity!

Let the white person again tread the black person under his heel! (Say! which is trodden under heel after all?)

Let the reflections of the things of the world be studied in mirrors! let the things themselves still continue unstudied! $(333-36)$

The $187 \mathrm{I}-72$ edition reveals Whitman's desire to negotiate precisely this issue of "Respondez" and U.S. history. It is as if, having included the poem among a group called "Marches Now the War is Over," he worried that his readers would associate these imperatives with a former, more fractured time, falling into the trap of thinking that its imperatives no longer obtain. The repeated use of "still" stands as a reminder for his readership not to forget its pertinence.

The experience of reading Whitman's poem confirms the justice of such a reminder. For one needs little knowledge of mid-nineteenthcentury politics to appreciate "Respondez." The dialectic applies almost equally well in the antebellum and postbellum as it does today. It is, in Ezra Pound's words, "news that STAYS news" (29). And it is also, fundamentally, an experimental or exploratory poem. Whitman often breaks his tone to make space for lyrical interludes: flashes of genuine curiosity which are difficult to read as representative of anything but themselves. These propositions revel in language itself. Where Erkkila's argument fails, I think, is in its assumption that Whitman's use of "Let" is consistent.

How then, if we are faced with an ever changing tone and ever changing set of propositions, are we to see this poem's relation to Amer- 
ica and American history? My suggestion is not to think of the Civil War as the only war of which this poem might be mimetic. Rather, as Michael Warner reminds us, a "queer politics" of "local struggles" almost always operates to some extent on a global background of "largescale social questions" ("Introduction" 7). Whitman's queering of politics and history makes the terms of the Civil War not only a national war but a war of every man against every man: "Let the Asiatic, the African, the European, the American, and the Australian, go armed against the murderous stealthiness of each other! Let them sleep armed! Let none believe in good will!" (320). The war in "Respondez" seems to be a war that Whitman saw as constitutive of, and yet also in many ways dialectically opposite to, democracy: capitalism. The lines quoted here follow shortly on a number of propositions in which Whitman presents a panorama of the products of what we might call "laissez faire" (or "Let" do) capitalism and individual ownership, such as: "Let there be money, business, railroads, imports, exports, custom, authority, precedents, pallor, dyspepsia, smut, ignorance, unbelief!" (3 I9). Or two lines later: "Let a floating cloud in the sky_-Let a wave of the sea—Let one glimpse of your eye-sight upon the landscape or grass_-Let growing mint, spinach, onions, tomatoes-Let these be exhibited as shows at a great price for admission!" (320). Even the natural world it seems-phenomena as free as clouds or waves-can be, and in this proposition have been, commodified, requiring "a great price for admission!" Whitman's "Let" in this sense is a reference to leasing, to putting a price on something, of letting something out to someone, of demanding payment.

Yet, as always in this poem, there is peace here and not only war. For a different emphasis on the last violently torqueing exclamation of the proposition allows us to read there an aesthetic statement: appreciate clouds and waves as if they were works of art. "Let" then is optative, "Let" as in "let wiser heads prevail" or the Beatles' "Let It Be." In this sense Whitman appears to cede responsibility to the poem. Meaning itself, and not just content, is to let-re-leased to a free play of juxtapositions without aesthetic hierarchy. It is an artistic perspective of anything goes, which might also relate to Whitman's own choice of form. By presenting these organic objects as art, he is writing an apology for his own all-inclusive verse-line, and demanding — even commanding—its indulgence.

Whitman is using the queer, polysemic, "criminal" significations of "Let" to produce a space that celebrates and resists capitalist control. As 
the stylistically anaphoric "Let" takes control of the poem, it strays far beyond the bounds of a logically constructed argument, accommodating contradiction in a way that ordinary propositions cannot. And via these contradictory propositions, one gets a sense of the whole scope of Whitman's concerns, from utopia to dystopia.

So why did Whitman decide to reduce this fifty-seven line poem, sprawling over six pages, to two fragments in $\mathrm{I} 88 \mathrm{I}-82$ ? I believe that while the other poems of Leaves of Grass were brought together to form a tale of these States, "Respondez" could not, and still cannot, be adequately nationalized or historicized or even assimilated in a larger work. Whitman, of course, has long been recognized as an internationalist poet, and the problem of reconciling his internationalism with his acclaimed Americanness is not limited to "Respondez." The usual "solution," as Walter Grünzweig calls it, is to read Whitman's internationalism through "his interpretation of America and American culture" (239). To this end Grünzweig quotes Whitman's famous line from Democratic Vistas saying that "democracy ... alone can bind, and ever seeks to bind, all nations, all men, of however various and distant lands, into a brotherhood, a family" (239). In other words, Grünzweig's "solution" depends on exporting democracy. Using the same principle, one might assume that we could show all of Whitman's international poems to be, at heart, American. Yet, where this may be possible for "Passage to India" or "Salut Au Monde!" because they present images of movement outwards from one point recognizable as Whitman's comprehensive encompassing democratic U.S., "Respondez" never takes a side or position, and never conclusively decides between democracy seen as freedom and its opposite: democracy exported for the purposes of export, that is, democracy as capitalism, a war of opinion, strife. "Respondez" is not loyal in the same way that Whitman's other works are-in fact it always speaks with the double-tongued voice of an equivocator, of one taking two or more sides at the same time, both for and against.

The final editions of Leaves of Grass tend toward the status of a romantic long poem, seeking a degree of closure in the name of democracy. "Respondez," however, remains open, presenting an anarchic critique that threatens the stability of this American epic. In this poem Whitman seems to have stumbled across a radical poetic practice where forms, terms, and direction are constantly reconsidered. It is unsurprising, therefore, that Marshall McLuhan saw fit to place "Respondez" 
alongside Marinetti's "Futurist Manifesto," or that this work should speak so powerfully to twentieth- and twenty-first-century avant-garde poets.

University of Pennsylvania

\section{NOTES}

I. All references to Leaves of Grass, unless otherwise noted, are to the I 856 Facsimile edition. In attacking the Library of America edition of Whitman, Abrams defends the omitted "Respondez," pointing out its importance to poets and critics alike. Although he mentions that its significance has been "acknowledged" by Kenneth Burke, Roger Asselineau, and Gay Wilson Allen, these acknowledgments are of a cursory kind. The most thorough treatment of the poem, which I turn to later in this essay, is Erkkila's in Whitman 54; 138-39; 162; 263; 289-90.

2. To be precise, "Respondez" was not entirely suppressed from the $\mathrm{I} 88 \mathrm{I}-82$ and I $89 \mathrm{I}-92$ "deathbed" editions. Rather, it appears in severely reduced form as the two short poems, "Transpositions" and "Reversals."

3. Creeley included the poem in his 1973 Penguin edition of selected poems. More recently "Respondez" has been included in Rothenberg and Robinson's Poems for the Millennium, Volume Three. Charles Bernstein read the poem at this anthology's launch parties at the Bowery Poetry Club on March 29, 2009, and at Kelly Writers House on October 7, 2009.

4. Zukofsky returns to the poem in Bottom, again quoting it without further comment (25I).

5. The most common and recognizable public use of the third person optative subjunctive is probably "God bless America," which clearly expresses a fervent desire, not a command.

6. This is an issue raised by McGill, who deals partly with the question of the speaker of "Respondez" (50).

7. "In choosing marriage partners they solemnly and seriously follow a custom which seemed to us foolish and absurd in the extreme. Whether she be widow or virgin, the woman is shown naked to the suitor by a responsible and respectable matron; and similarly, some honourable man presents the suitor naked to the woman" (More 79).

8. Campbell cites "Respondez" in a list of poems cut from Leaves of Grass because of Whitman's self-censorship: a "gain in taste," which "appears especially in his suppression of sundry indelicate passages dealing with sex" (257). The extent to which "Respondez" deals with sex is questionable. Lowenfels included "Respondez" in his I970 anthology, but the choice was opposed by White in his review. "Why the editor chose to omit 'A Sight in Camp inthe Day-break Grey and Dim' is indeed a mystery," writes White. "It is a very tender and erotic poem which treats of manly love throughout. Instead, Lowenfels chose to include one of Whitman's 
poorest poems. Like many great poets, Whitman did write some very bad poetry. 'Respondez' is one of the weakest. It is tedious, pedantic, repetitious, and essentially non-erotic" (653).

9. The terms are Nathanson's (75). My ideas about the performativity of Whitman's persona here are also indebted to the work of Michael Moon and Eve Kosofsky Sedgwick.

Io. I have taken the idea of a queer politics from Warner, "Introduction."

I I. These ideas are indebted to Warner's understanding of the public sphere in Letters of the Republic.

I2. For a more detailed discussion of this term, see Bercovitch I9I-97.

I3. Erkkila relates "Respondez" and "Resurgemus" to the French Revolution and the revolutions of $\mathrm{I} 848$ and $\mathrm{I} 870-7 \mathrm{I}$, emphasizing the political significance of Whitman's use of French words ("To Paris" 7-22).

I4 A similar argument is put forward by Wynn who notes that in his later poetry, "Whitman is, to his great psychological relief, able to discover the ideal to be immanent in many aspects of contemporary life, so rendering it once more fit (as the America of "Respondez" is not) for proper human habitation" (37).

\section{WORKS CITED}

Abrams, Sam. "What Is This You Bring My America?": The Library of America Whitman." Modern Language Studies 26.2/3 (1996): 19-52.

Adorno, Theodor W., and E. B. Ashton. Negative Dialectics. London: Routledge \& Kegan Paul, I973.

Allen, Gay Wilson. A Reader's Guide to Walt Whitman. New York: Farrar, Straus \& Giroux, I970.

. The Solitary Singer: A Critical Biography of Walt Whitman. Reissue with revisions ed. New York: New York University Press, I967.

Althusser, Louis. "Ideology and Ideological State Apparatuses." Lenin and Philosophy. Trans. B. Brewster. New York: Monthly Review Press, I97 I. I 27-86.

Arac, Jonathan. "Whitman and Problems of the Vernacular." Erkkila and Grossman 44-6r.

Asselineau, Roger. The Evolution of Walt Whitman. Cambridge: Belknap-Harvard University Press, I962.

Bakhtin, M.M. Rabelais and His World. Trans. Helene Iswolsky. Cambridge: MIT Press, I968.

Bercovitch, Sacvan. The American Jeremiad. Madison: University of Wisconsin Press, 1978.

Billitteri, Carla. Language and the Renewal of Society in Walt Whitman, Laura (Riding) Jackson, and Charles Olson: The American Cratylus. New York: Palgrave-Macmillan, 2009. 
Borges, Jorge Luis. "The Secret Miracle.” Ficciones. New York: Grove Press, I962. I $45-50$.

Burke, Kenneth. The Philosophy of Literary Form: Studies in Symbolic Action. Berkeley: University of California Press, I973.

Butler, Judith. Bodies That Matter: On the Discursive Limits of "Sex." New York: Routledge, I993.

Campbell, Killis. "The Evolution of Whitman as Artist." American Literature 6 (I934): 254-63.

Creeley, Robert, ed. Whitman. Harmondsworth, UK: Penguin, I973.

Erkkila, Betsy. "To Paris With My Love': Whitman among the French Revisited." Revue Française d'Études Américaines 108 (2006): 7-22.

- Whitman: The Political Poet. New York: Oxford University Press, I989.

—, and Jay Grosman, eds. Breaking Bounds: Whitman and American Cultural Studies. New York: Oxford University Press, I996.

Foucault, Michel. The History of Sexuality. New York: Pantheon Books, 1978.

Grünzweig, Walter. “For America-For All the Earth': Walt Whitman as an International(ist) Poet." Erkkila and Grossman 238-50.

Hollander, John. Melodious Guile: Fictive Pattern in Poetic Language. New Haven: Yale University Press, I988.

Lewis, R.W.B. The American Adam; Innocence, Tragedy, and Tradition in the Nineteenth Century. Chicago: University of Chicago Press, I955.

Love, Heather. Feeling Backward: Loss and the Politics of Queer History. Cambridge: Harvard University Press, 2007.

Lowenfels, Walter, ed. The Tenderest Lover: The Erotic Poetry of Walt Whitman. New York: Dell, I970.

McGill, Meredith L. "Walt Whitman and the Poetics of Reprinting." Walt Whitman, Where the Future Becomes the Present. Ed. David Haven Blake and Michael Robertson. Iowa City: University of Iowa Press, 2008. 37-58.

McLuhan, Marshall, and Victor J. Papanek. Verbi-Voco-Visual Explorations. New York: Something Else Press, 1967.

Miller, Perry. Nature's Nation. Cambridge: Belknap-Harvard University Press, I 967.

More, Thomas. Utopia: Latin Text and English Translation. Ed. George M. Logan, Robert M. Adams, and Clarence H. Miller. New York: Cambridge University Press, I 995.

Nathanson, Tenney. Whitman's Presence: Body, Voice, and Writing in Leaves of Grass. New York: New York University Press, 1992.

Orwell, George. 1984. I949. San Diego: Harcourt Brace Jovanovich, I984.

Pound, Ezra. ABC of Reading. New York: J. Laughlin, I960.

Reynolds, David S. A Cultural Biography. New York: Vintage Books, 1996.

Rothenberg, Jerome, and Jeffery C. Robinson, eds. Poems for the Millennium, Volume Three: The University of California Book of Romantic $\mathcal{E}$ Postromantic Poetry. Berkeley: University of California Press, 2009. 
Warner, Michael. The Letters of the Republic: Publication and the Public Sphere in Eighteenth-Century America. Cambridge: Harvard University Press, I 990. . "Introduction: Fear of a Queer Planet." Social Text 9.4 ( I991 ): 3-I 7.

White, William M. "Review: Walt Whitman's Erotic Poetry: New as Foam and Old as the Rock." The Sewanee Review 79 (1971): 650-54.

Whitman, Walt. Daybooks and Notebooks. Vol. 3. Ed. William White. New York: New York University Press, I978.

- Leaves of Grass: A Facsimile of the First Edition. 1855. Ed. Richard Bridgman. San Francisco: Chandler Publishing, i 968.

- Leaves of Grass. i 856. Facsimile Ed. Ann Arbor: Microfilm International, I980.

- Leaves of Grass: Facsimile Edition of the I860 Text. Ed. Roy Harvey Pearce. Ithaca: Cornell University Press, I96r.

- Leaves of Grass. 1867. Walt Whitman Archive. 9 July $2013<$ http://www. whitmanarchive.org/published/LG/1867/whole.html>

. Leaves of Grass. 1871-72. Walt Whitman Archive. 9 July $2013<$ http://www. whitmanarchive.org/published/LG/1871/whole.html>

Wynn, Thomas M. The Lunar Light of Whitman's Poetry. Cambridge: Harvard University Press, I987.

Zukofsky, Louis, and Mark Scroggins, eds. Prepositions + : The Collected Critical Essays. Hanover, NH: University Press of New England for Wesleyan University Press, 2000.

-, and Celia Thaew Zukofsky. Bottom: On Shakespeare. Complete ed. Vol. I. Middletown, CT: Wesleyan University Press, 2002.



